\title{
SORLA/SORL1, a Neuronal Sorting Receptor Implicated in Alzheimer's Disease
}

\author{
Thomas E. Willnow, Anne-Sophie Carlo, Michael Rohe and Vanessa Schmidt \\ Max-Delbrueck-Center for Molecular Medicine, Robert-Roessle-Str. 10, D-13125 Berlin, Germany
}

\section{SYNOPSIS}

The proteolytic breakdown of the amyloid precursor protein (APP) to neurotoxic amyloid- $\beta$ peptides in the brain has been recognized as a major pathological pathway in Alzheimer's disease (AD). Yet, the factors that control the processing of APP and their potential contribution to the common sporadic form of AD remain poorly understood. Here, we review recent findings from studies in patients and in animal models that led to the identification of a unique sorting receptor for APP in neurons, designated SORLA/SORL1, that emerges as a key player in amyloidogenic processing and as major genetic risk factor for $\mathrm{AD}$.

\section{KEY WORDS}

APP, BDNF, neurodegeneration, protein trafficking, SORLA/LR11, secretases, VPS10P domain

\section{INTRODUCTION}

The amyloid hypothesis represents the major current concept to describe the cellular and pathological events underlying neurodegenerative

Accepted: April 4, 2010

Address for correspondence:

Thomas E. Willnow

Max-Delbrueck-Center for Molecular Medicine

Robert-Roessle-Str. 10, D-13125 Berlin, Germany

Phone: +49-30-9406-2569; Fax: +49-30-9406-3382

E-mail: willnow@mdc-berlin.de processes in Alzheimer's disease (AD) /19/. Central to this hypothesis is the amyloid precursor protein (APP), a type-1 membrane protein expressed in many neuronal and non-neuronal cell types. In cells, including neurons in the brain, APP undergoes two alternative proteolytic processing pathways that generate multiple soluble as well as membrane-associated fragments from this polypeptide (Figure 1A, inset). The physiological relevance of APP processing is a focus of intense investigation and numerous functions have been assigned to the precursor and its processing products (Figure 1A). In terms of neurodegeneration, the conversion of APP to a 40 to 42 amino acid amyloid- $\beta$ peptide $(A \beta)$ through sequential cleavage by $\beta$ - and $\gamma$-secretases is noteworthy. $A \beta$ forms neurotoxic oligomers and senile plaques, pathological hallmarks of $\mathrm{AD} / 9,37,79 /$.

Evidence that the extent of proteolytic breakdown of APP to A $\beta$ is a determinant of onset and progression of $\mathrm{AD}$ comes from rare inheritable (familial) forms of the disease that are caused by defects in the genes encoding APP or presenilin-1 and -2 , components of the $\gamma$-secretase complex $/ 69 /$. Typically, these mutations are associated with an overall increase in $A \beta$ peptide production or with a shift towards generation of the more amyloidogenic variant $A \beta_{42}$. Also, carrying an extra copy of the APP gene as in trisomy 21 is invariably associated with occurrence of AD at an early age.

Despite APP processing being critical to AD development, our understanding of the underlying regulatory mechanisms is rather incomplete. Thus, the goal has been to identify neuronal factors that control the metabolism of APP and to determine whether alterations in these pathways contribute to the common sporadic forms of the disease that afflict $90 \%$ of all patients.

Key to understanding APP processing is the complex trafficking behavior of the precursor 


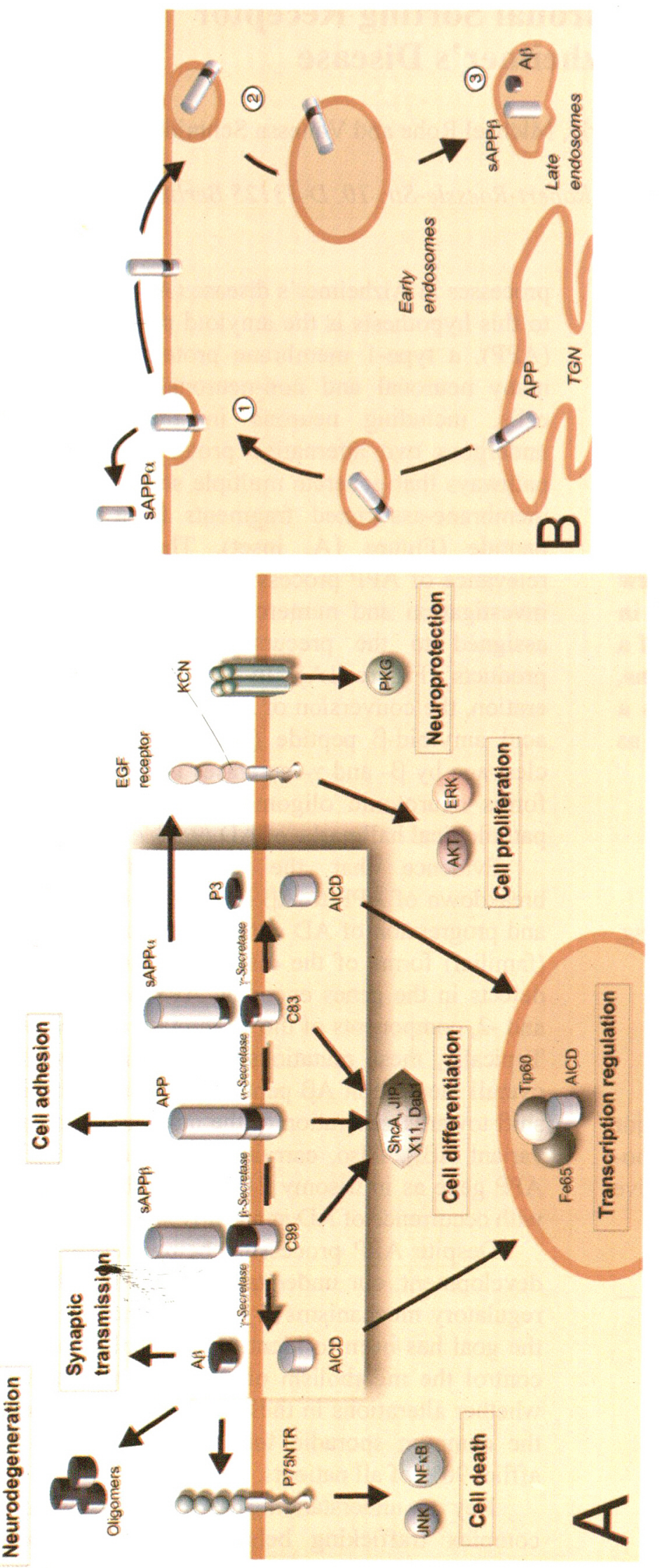

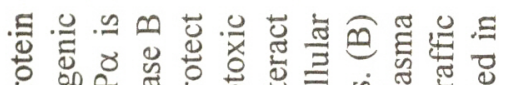

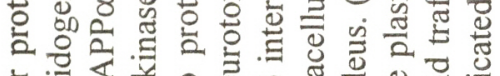

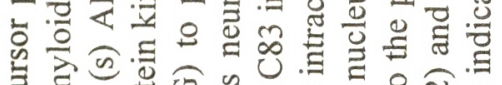

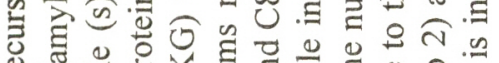

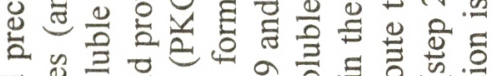

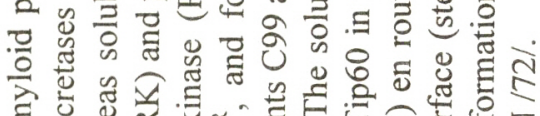

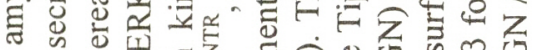

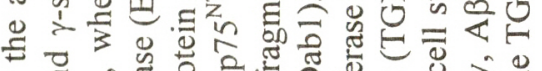

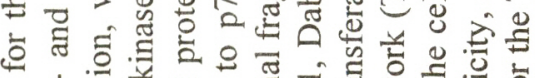

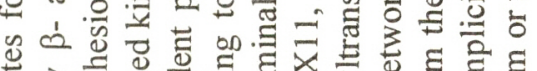

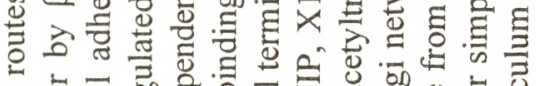
on

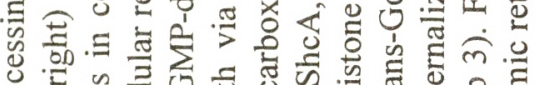

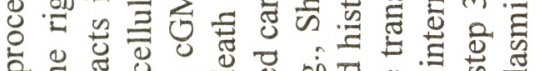

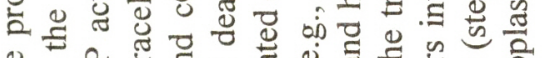

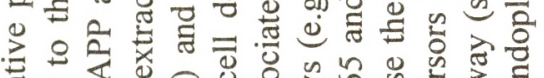

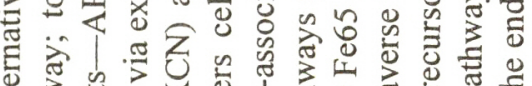

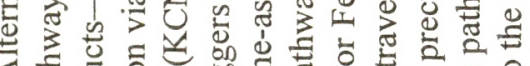
$<5$

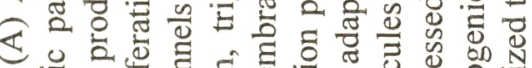
.

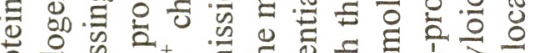

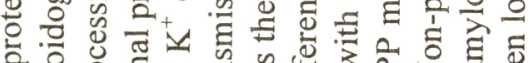

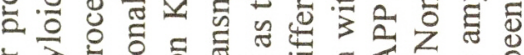

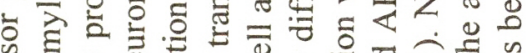

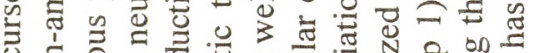

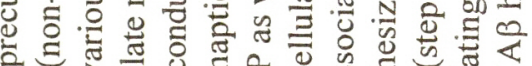

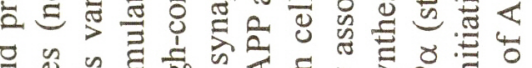

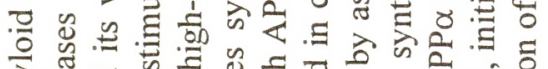

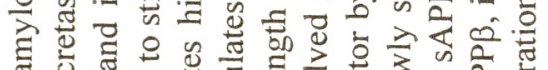

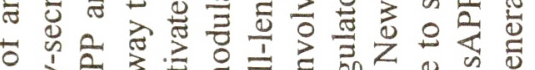

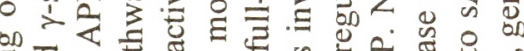

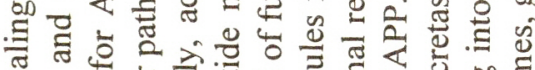

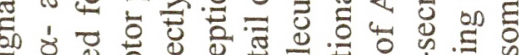
के

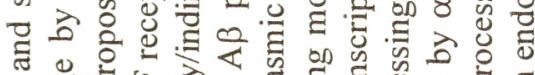

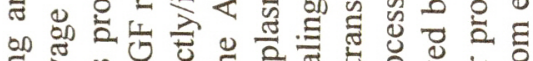

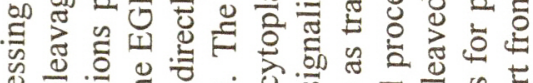

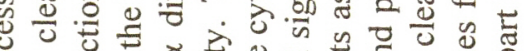

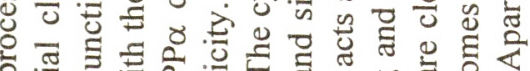

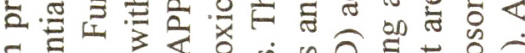

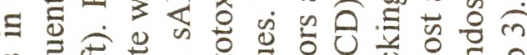

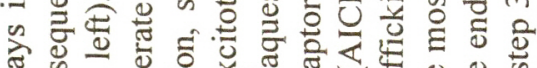

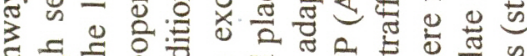

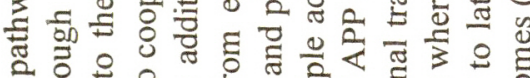

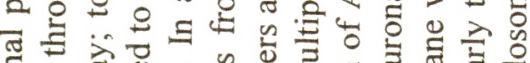

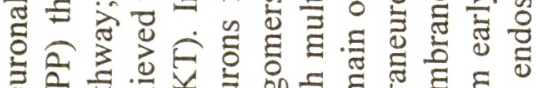

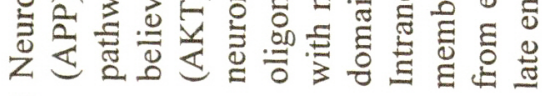
$\ddot{-}$ in 


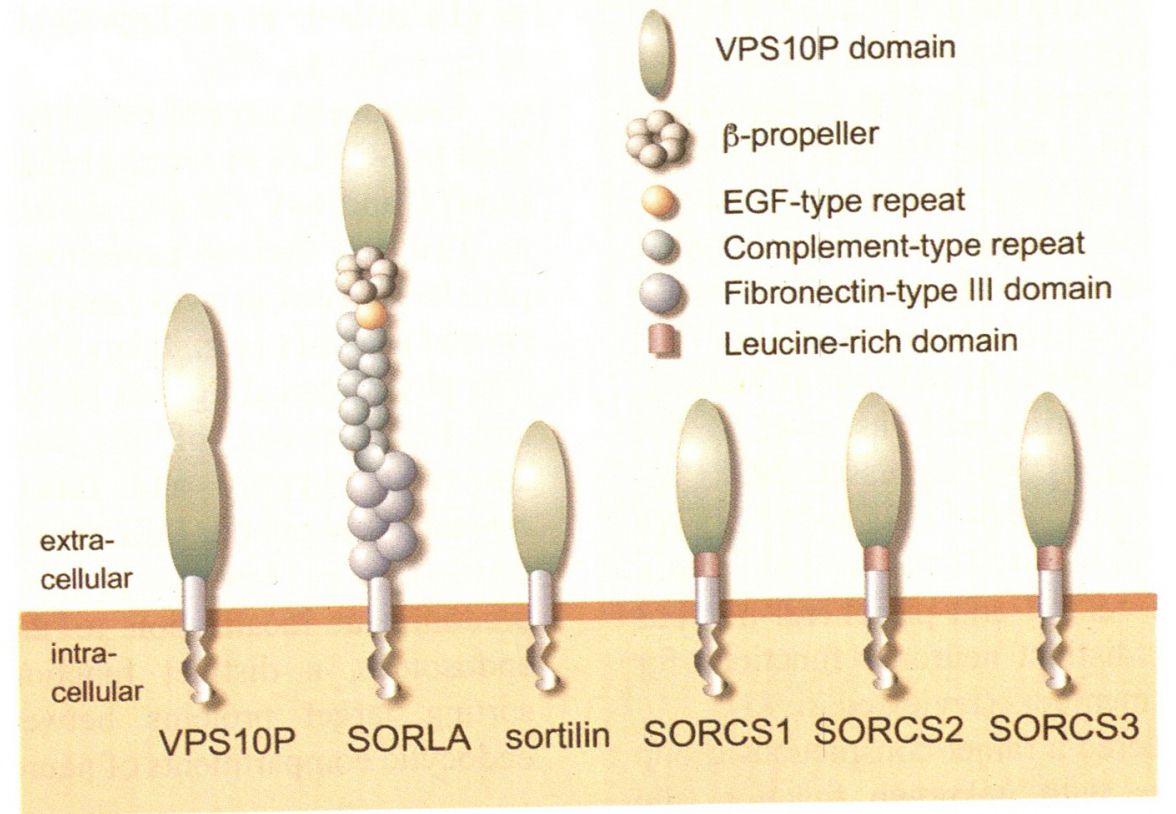

Fig. 2: Structural and evolutionary conservation of VPS10P domain receptors. Structural organization of vacuolar protein sorting 10 protein (VPS10P) domain receptors from yeast (VPS10P) and humans (SORLA, sortilin, SORCS-1, -2, -3). The extracellular domains of the receptors are either composed of one (sortilin, SORLA, SORCS-1, -2, and -3) or two VPS10P domains (VPS10P) which function as ligand binding sites. In addition, receptors may carry additional modules involved in protein-protein interaction (leucine-rich domains, complement-type repeats, EGF-type repeats and fibronectin-type III domains) or regulation of ligand binding ( $\beta$-propeller). SORLA, sorting protein-related receptor with A-type repeats; SORCS, sortilin-related receptor CNS expressed.

protein through the intracellular compartments of neurons that determine its processing fate (Figure 1B). Most APP molecules are cleaved by $\alpha$-secretase at or near the plasma membrane to produce soluble (s)APP $\alpha$. Some precursor molecules, however, are re-internalized from the cell surface and delivered to late endosomes for $\beta$-secretase (and subsequent $\gamma$-secretase) processing to sAPP $\beta$ and $A \beta$ (Figure 1B). The importance of regulated intracellular transport of APP for A $\beta$ production is underscored by findings that faulty trafficking of APP through endocytic and secretory compartments of the cell contributes to AD-related processes $/ 30,50,55,72 /$.

Recently, a breakthrough in solving the puzzle of APP transport and processing came with the identification of a neuronal sorting receptor for APP called sorting protein-related receptor with A-type repeats (SORLA). Independent lines of evidence from histopathological analyses of individuals with sporadic $\mathrm{AD}$, to epidemiological studies in patient cohorts, to investigations in cell and animal models all converged on this novel receptor as a chief regulator of APP processing. In this review, we will summarize the latest findings on the sorting receptor SORLA, which is now considered one of the most important risk factors in sporadic $\mathrm{AD}{ }^{1}$

\section{SORLA, AN INTRACELLULAR SORTING PROTEIN IN NEURONS}

SORLA, also known as SORL1 or LR11, member of the VPS10P domain receptor family /24,83/ (Figure 2). The name derives fr structural motif common to all family men the VPS10P domain. It is a 700 amino acid $n$

\footnotetext{
${ }^{1}$ Bertram L, Tram L, McQueen MB, Mullin K, Blacker RE. Systematic meta-analyses of Alzheimer disease ge' ciation studies: the AlzGene database. Nat Genet 200' 23. http://www.alzgene.org. Accessed [05.03.2010.
} 
that forms a large 10-bladed $\beta$-propeller fold and composes part of the extra-cellular domain of all receptors $/ 58 /$. The domain was first recognized in the vacuolar protein sorting 10 protein (hence VPS10P domain), a sorting protein in Saccharomyces cerevisiae that directs lysosomal enzymes from the Golgi to the vacuole (the yeast 'lysosome') 143/. Five VPS10P domain receptors are found in vertebrates, including man. In addition to SORLA, these proteins are sortilin $/ 57 /$ as well as the sortilin-related receptor CNS expressed (SORCS)$1 / 20 \%$, SORCS-2 /60/, and SORCS-3 /18/. All receptors are predominantly found in defined cell populations of the central and peripheral nervous system, indicating distinct neuronal functions for the various family members (reviewed in $/ 81 /$ ).

Initially considered a rather conspicuous group of sorting proteins with unknown function, the mammalian receptors of the gene family recently surfaced as potential neuronal disease genes in a number of association studies in patients. These diseases encompass Alzheimer disease (AD) and other types of age-related dementias (SORLA, SORCS1) $/ 36,16 /$, bipolar disorders (SORCS2) $/ 4 /$, and senescence of the nervous system (sortilin) 140\%. The functional relevance of VPS10P domain receptors for the nervous system was confirmed by studies that uncovered sortilin as a receptor for neurotrophins in the control of neuronal cell death $126 /$.

SORLA is a $250-\mathrm{kDa}$ protein widely expressed in neurons throughout the mammalian CNS (Figure 3A-D). In the mouse, expression starts at mid-gestation but increases significantly in the postnatal and adult brain $/ 29 /$. In both rodent and human adult brain tissue, expression of the receptor is strongest in the cerebral and entorhinal cortex, hippocampus, cerebellum, and brain stem $/ 11,45,53 /$. At the subcellular level, immunoreactivity for the receptor is restricted to the somatodendritic compartment (Figure 3E), where it mainly localizes to intracellular vesicles in the perinuclear region (Figure 3F) /1,11/. Co-immunostaining with markers of various intracellular compartments identified these subcellular structures as trans-Golgi network (TGN) and early endosomes in primary neurons and in established cells lines expressing the receptor $148,53,66,74 /$. In contrast to neurons, little if any expression is seen in glia cells or in cerebrovascular endothelial cells in the brain $/ 41,45 /$.

Previously, several proteins were identified that bind to SORLA in vitro, including apolipoproteins (apo) $\mathrm{E}$ and $\mathrm{A}-\mathrm{V} / 23,49 /$, signaling molecules such as glial cell derived neurotrophic factor $/ 80 /$ and platelet derived growth factor-BB $/ 14 /$, as well as certain enzymes (e.g., lipoprotein lipases) $/ 23 /$.

The physiological ligands for SORLA in the brain and the relevance of this receptor pathway for structural integrity and function of the CNS remained enigmatic. Still, based on the structural similarity to other sorting proteins and its predominant localization to the TGN and early endosomes, a distinct function for SORLA in sorting target proteins between secretory and endocytic compartments of neurons seemed likely.

\section{SORLA/SORL1, a risk gene in sporadic AD}

The involvement of SORLA in AD was initially suggested by Lah and colleagues $/ 65 /$, who used gene expression profiling to demonstrate low levels of SORLA transcript in lymphoblasts from patients with sporadic AD. The decreased mRNA levels coincided with a reduced expression of the receptor in the brain areas most vulnerable to neurodegeneration, including the frontal cortex and hippocampus, as shown by immunohistology. Expression of the receptor in other brain areas like the cerebellum was not affected $153 /$. Reduced amounts of SORLA in the brain were also found in individuals with mild cognitive impairment, a condition that may represent prodromal $\mathrm{AD} / 64 /$. In contrast, normal expression of the receptor was documented in individuals with familial forms of $\mathrm{AD} / 11 /$, suggesting that impaired receptor expression represents a primary event in sporadic $\mathrm{AD}$ rather than a secondary consequence of neurodegeneration. Loss of receptor expression also manifests itself in lower levels of SORLA degradation products in the cerebrospinal fluid of affected individuals $/ 41 /$.

What could be the mechanism that determines SORLA levels in the brain and elsewhere in the organism? Evidence from association studies argues that the determination may lie in allelic receptor gene variants in the human population. As shown in a pioneering study by Rogaeva et al. /61/ 
A

CTX

Sub

\section{CA1}
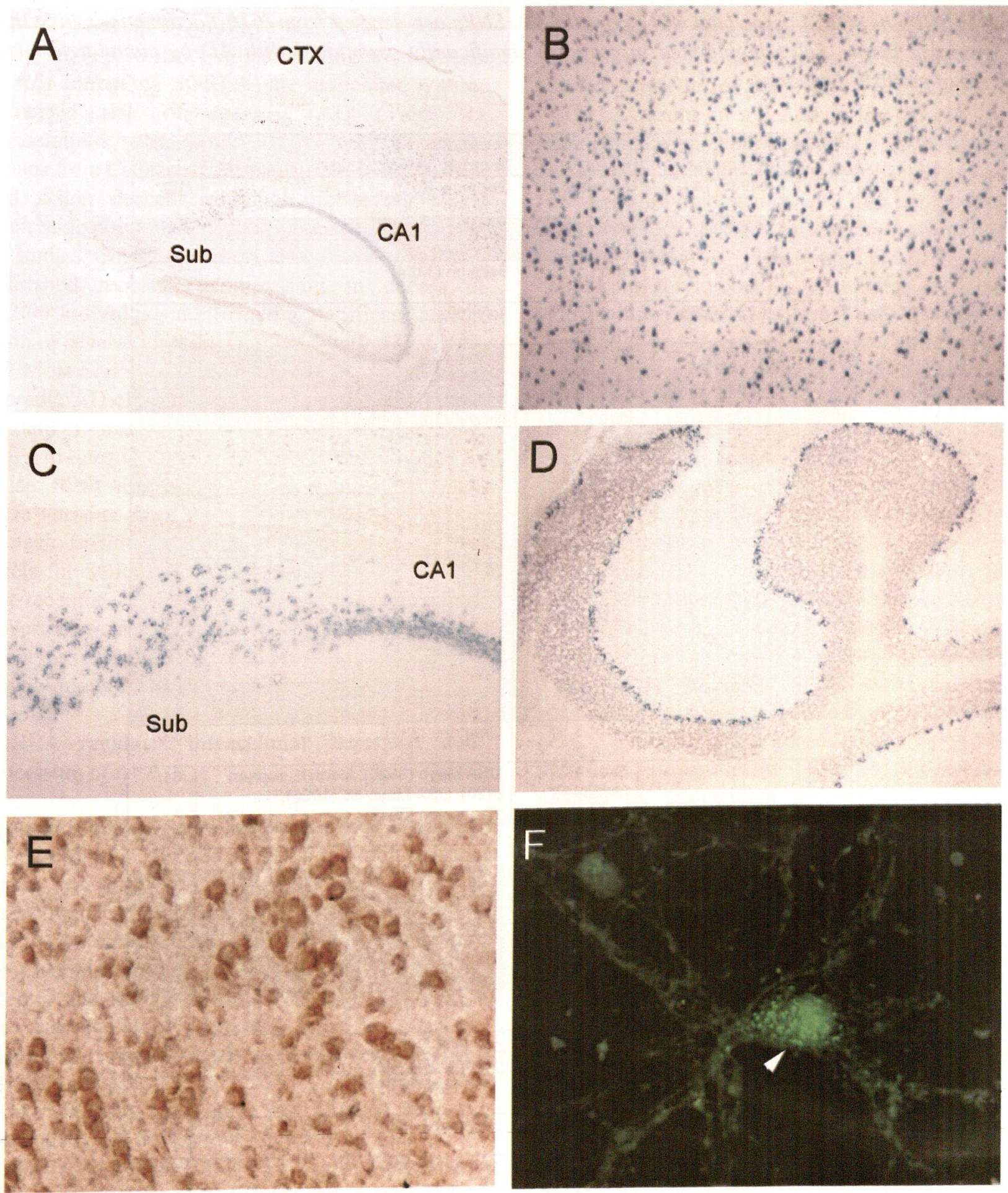

Fig. 3: Expression of SORLA in the adult mouse brain. (A-D) Detection of SORLA expression in subiculum (Sub) and CA1 region of the hippocampus and layer $\mathrm{V}$ of the cortex (CTX) based on activity of a $\square$ galactosidase reporter gene (lacZ) inserted into the Sorll locus in mice /62/. Higher magnifications of lacZ positive layer V neurons in cerebral cortex (B), pyramidal neurons in subiculum and CA1 region of the hippocampus $(C)$, and Purkinje cells in the cerebellum (D) are shown. (E) Immunohistological detection of SORLA in the soma of cortical neurons. (F) Immunofluorescence microscopy indicating SORLA localization to vesicles in the perinuclear (Golgi) region in primary mouse cortical neurons (arrowhead). 
Table 1: SNPs in SORLI associated with sporadic AD. SNPs are derived from /61/. Localizations in SORLI are presented below. SNPs highlighted in grey are significantly associated with AD by cumulative metaanalyses of published reports. ${ }^{2}$

\begin{tabular}{|c|c|c|c|c|}
\hline Marker & $\begin{array}{l}\text { dbSNP } \\
\text { rs number }\end{array}$ & $\begin{array}{l}\text { SNP position } \\
\text { (type) }\end{array}$ & $\begin{array}{l}\text { Population } \\
\text { (number of individuals) }\end{array}$ & Study \\
\hline 1 & rs4935774 & $\begin{array}{l}\text { Upstream of } \\
\text { 5'UTR }\end{array}$ & Germany (970) & 1131 \\
\hline \multirow[t]{2}{*}{4} & \multirow[t]{2}{*}{ rs661057 } & \multirow{2}{*}{ Intron 1} & USA Mayo (3529), Caucasian (3949) & 1611 \\
\hline & & & Italy $(609)$ & 181 \\
\hline 6 & rs560573 & Intron 5 & Belgium (1184) & 151 \\
\hline 7 & rs12364988 & $\begin{array}{l}\text { Exon } 6 \\
(\mathrm{H} 269 \mathrm{H})\end{array}$ & Italy (609) & 181 \\
\hline \multirow[t]{2}{*}{8} & \multirow[t]{2}{*}{ rs 668387} & \multirow[t]{2}{*}{ Intron 6} & $\begin{array}{l}\text { Israel (225), North European (420), } \\
\text { Caucasian (3949) }\end{array}$ & 1611 \\
\hline & & & Belgium (1184) & 151 \\
\hline \multirow[t]{2}{*}{9} & \multirow[t]{2}{*}{ rs689021 } & \multirow[t]{2}{*}{ Intron 6} & Israel (225), North European (420) & 1611 \\
\hline & & & Belgium (1184) & 151 \\
\hline \multirow[t]{3}{*}{10} & \multirow[t]{3}{*}{ rs 641120} & \multirow[t]{3}{*}{ Intron 6} & Israel (225) & 1611 \\
\hline & & & Belgium (1184) & 151 \\
\hline & & & Italy (609) & 181 \\
\hline \multirow[t]{2}{*}{12} & \multirow[t]{2}{*}{ rs12285364 } & \multirow[t]{2}{*}{ Intron 9} & $\begin{array}{l}\text { USA Mayo AUT ( } 853), \text { USA Mayo } \\
(3529)\end{array}$ & 1611 \\
\hline & & & $\begin{array}{l}\text { African-American (246), Caribbean } \\
\text { Hispanics ( } 372 \text { ) }\end{array}$ & 1361 \\
\hline \multirow[t]{3}{*}{19} & \multirow[t]{3}{*}{ rs2070045 } & \multirow[t]{3}{*}{$\begin{array}{l}\text { Exon } 25 \\
\text { (S1184S) }\end{array}$} & $\begin{array}{l}\text { North European (420), USA Mayo } \\
(3529) \text {, Caucasian }(3949)\end{array}$ & 1611 \\
\hline & & & UK1 $(689)$ & 1381 \\
\hline & & & Japan $(888)$ & 1311 \\
\hline 20 & rs3824966 & Intron 25 & Caucasian USA (106) & 1361 \\
\hline 21 & $\begin{array}{l}\text { SORL1- } \\
18 \mathrm{e} \times 26\end{array}$ & $\begin{array}{l}(-18) 5^{\prime} \text { of } \\
\text { exon } 26\end{array}$ & Germany (832) & 1331 \\
\hline \multirow[t]{3}{*}{23} & \multirow[t]{3}{*}{ rs3824968 } & \multirow[t]{3}{*}{$\begin{array}{l}\text { Exon } 34 \\
(\mathrm{~A} 1584 \mathrm{~A})\end{array}$} & $\begin{array}{l}\text { USA Mayo (3529), North European } \\
\text { (420), USA Mayo JS (1026), } \\
\text { Caucasian (3949) }\end{array}$ & $161 /$ \\
\hline & & & China (486) & 1751 \\
\hline & & & Japan (888) & 1311 \\
\hline \multirow[t]{2}{*}{24} & \multirow[t]{2}{*}{ rs2282649 } & \multirow[t]{2}{*}{ Intron 38} & $\begin{array}{l}\text { USA Mayo (3529), USA Mayo JS } \\
(1026) \text {, Caucasian ( } 3949)\end{array}$ & 1611 \\
\hline & & & Japan $(888)$ & 1311 \\
\hline \multirow[t]{2}{*}{25} & \multirow[t]{2}{*}{ rs1010159 } & \multirow[t]{2}{*}{ Intron 39} & $\begin{array}{l}\text { USA Mayo ( } 3529) \text {, USA Mayo JS } \\
(1026) \text {, Caucasian (3949) }\end{array}$ & 1611 \\
\hline & & & Japan (888) & $|31|$ \\
\hline 26 & rs1784933 & Intron 41 & African-American (246) & $136 \mid$ \\
\hline \multirow[t]{2}{*}{27} & \multirow[t]{2}{*}{ rs1614735 } & \multirow[t]{2}{*}{ Intron 45} & Belgium (1184) & 151 \\
\hline & & & Germany $(970)$ & $113 /$ \\
\hline new & rs12576704 & Upstream & Germany (970) & 1131 \\
\hline new & rs10502262 & Intron 13 & Germany (970) & $/ 13 /$ \\
\hline new & rs3781835 & $\begin{array}{l}\text { Exon } 25 / \text { Intron } \\
25 \text { boundary }\end{array}$ & Germany (970) & 1131 \\
\hline & 4 & 91012 & 19,20 & \\
\hline
\end{tabular}

${ }^{2}$ http://www.alzgene.org. Accessed 5 Mar 2010 
and followed up by multiple additional epidemiologic studies, distinct allele variations in human SORLI (encoding SORLA) are associated with an increased risk of sporadic AD (Table 1). Associations were found across multiple ethnic groups from Caucasian, Hispanic, African-American, and Asian descent, although not every single nucleotide polymorphism (SNP) was reproduced in all studies. Cumulative meta-analyses on previously published reports encompassing in excess of 13,000 individuals confirmed a significant association of several markers in SORL1 with AD $/ 59 / .^{3}$

Most SNPs in SORLI that are associated with sporadic AD cluster in two haplotype blocks in the 5'- and 3'- region of the gene (Table 1). As all SNPs in question are located in intronic regions or cause silent mutations, the mechanism whereby these variants predispose to sporadic $A D$ remains unclear. In line with reduced mRNA and protein levels for SORLA in AD patients, genetic control of receptor expression seems a possibility. Nevertheless, a correlation between distinct SORL1 genotypes and protein levels still awaits unambiguous documentation.

\section{SORLA regulates intracellular transport and processing of APP}

In the initial report implicating low levels of SORLA with occurrence of AD, a function for this orphan receptor in apoE clearance in brain parenchyma was proposed $/ 65 /$. Although a role for SORLA in apoE catabolism cannot be ruled out, the predominant intracellular localization of the receptor and a poor endocytic capacity compared with classical apoE receptors (e.g., low-density lipoprotzin receptor) argue against such an activity $/ 21,48,66 /$.

An alternative function for SORLA that is relevant to $\mathrm{AD}$ was first reported by Andersen et al. /1/, who demonstrated that SORLA directly binds APP and thereby affects the intracellular transport and processing of the precursor protein. The interaction involves binding sites in the extracellular domains and in the cytoplasmic domains of both proteins $/ 1,2,74 /$. In particular, fine mapping identified a binding epitope within the cluster of

${ }^{3}$ http://www.alzgene.org. Accessed 5 Mar 2010

VOLUME 21, NO. 4, 2010 complement-type repeats in SORLA (see Figure 2) that forms a 1:1 stoichiometric complex with the carbohydrate-linked domain of APP /2/. Binding to SORLA results in a sequestration of APP in the TGN and an impaired transition to the cell surface, effectively reducing the extent of APP cleavage through amyloidogenic and non-amyloidogenic pathways $/ 1,53,66 /$. Also, interaction with SORLA blocks access of $\beta$-secretase to APP, further impairing amyloidogenic processing /74/. These initial observations in cultured cells established a negative correlation between SORLA activity and conversion of APP to $A \beta$, providing a working hypothesis on why low levels of this receptor in some individuals may predispose to enhanced APP turnover and to sporadic $\mathrm{AD} / 3 /$.

Given the proposed role for SORLA in directing APP transport through neuronal compartments harboring secretase activities, the signals that govern intracellular trafficking of the receptor warrant particular attention. Like other members of the VPS10P-domain receptor family, SORLA is produced as inactive precursor carrying a 53 amino acid pro-peptide at the amino terminus that is required to fold the receptor polypeptide properly 123/. Upon transport through the constitutive secretory pathway to the TGN, the pro-peptide is cleaved by convertases to produce the mature receptor /23/. From the TGN, newly synthesized SORLA moves to the cell surface where it exhibits rapid internalization that is mediated by an 'acidic cluster dileucine' motif in the cytoplasmic receptor domain /48/. Following internalization, SORLA molecules relocate from early endosomes back to the TGN, avoiding transit to late endosomal compartments. This step is unique and not seen with endocytic receptors that deliver their cargo to late endosomes before moving back to the plasma membrane. In contrast, internalized SORLA molecules do not return to the cell surface but rather appear to cycle between late secretory and early endocytic organelles $/ 48,49 /$.

What evidence has been found that the peculiar trafficking behavior identified for SORLA in Chinese hamster ovary or human embryonic kidney cells bears any relevance for AD? Firstly, the central role of the Golgi in APP metabolism is well appreciated as the processing of APP requires an efficient transit of the precursor through this 
organelle /17,84/. Experimentally disrupting Golgi transition blocks APP processing /30,55/ whereas treatment that enhances membrane shunt from TGN to plasma membrane increases it $/ 82 \%$. Also, tempering with sorting of APP between endocytic and Golgi compartments reduces APP cleavage 168\%. All the above argues for the existence of factors (such as SORLA) in control of APP sorting at the TGN. Secondly, targeting SORLA to the wrong intracellular compartment results in an accumulation of APP in the very same location and an altered processing fate. For example, the coexpression of APP with SORLA mutants that are not retained in the TGN but sequester at the plasma membrane causes a shunt of APP to the cell surface and a massive increase in amyloidogenic processing. This effect is likely due to an increased number of APP molecules undergoing endocytosis, a pre-requisite for $A \beta$ production /66/. Thirdly, several cytosolic adaptor proteins that regulate protein transport between early endosomes and TGN have been implicated in AD. Previously, their mode of action in APP metabolism remained unclear, but new findings that these adaptors control trafficking of SORLA provide the missing functional link. Two such adaptor complexes, GGAs and retromer, are discussed in the following.

\section{CYTOSOLIC ADAPTOR PROTEINS IN CONTROL OF APP METABOLISM}

The Golgi-localizing, $\boldsymbol{\gamma}$-adaptin ear homology domain, $\underline{A} R$ F-interacting proteins (GGA1, GGA2, and $\mathrm{GCA} 3$ ) are three related adaptors that select cargo proteins at the TGN for transport to endosomes. The proteins bind a tetrapeptide motif Asp-Val-Pro-Met that is also present in the tail of SORLA $125 \%$. A disruption of this binding motif impairs the proper recycling of SORLA and, consequently, alters APP processing $/ 66 /$. Remarkably, previous studies have implicated GGA-1 in APP metabolism in as much as reduced expression of the adaptor enhances, whereas overexpression decreases $A \beta$ formation $/ 77 /$. These effects are independent of a direct interaction between APP and GGAs, suggesting that SORLA may be required to tether both components $/ 78 /$.
Also, decreased levels of GGA1 and GGA3 are seen in brain autopsy specimens from AD patients /76,78/.

As well as altered anterograde sorting, defects in reverse (or retrograde) sorting from endosomes to the TGN have also been linked to abnormal APP transport. Retromer is a tetrameric adaptor complex composed of VPS35, VPS29, VPS26, and sorting nexin $1 / 2$ that mediates the retrograde sorting of cargo (reviewed in $/ 67,71 /$ ). VPS35 and VPS26 are poorly expressed in $A D$ brain autopsies /73/, and disruption of the $V p s 35$ gene in mice results in memory deficits and synaptic dysfunctions associated with elevated $A \beta$ levels $/ 46 /$. Given the interaction between mammalian retromer and SORLA $/ 46 /$, defects in retromer-guided recycling of SORLA could be a cause of neurodegenerative processes $/ 51 /$.

In conclusion, substantial experimental evidence from histopathological and cell biological studies suggest a model whereby SORLA acts as sorting receptor for APP at the TGN (Figure 4). SORLA seems to prevent transport into the intracellular pathways required for processing, thereby acting as negative regulator of $A \beta$ production.

Because it recognizes interaction motifs both in the extracellular $/ 2 /$ and in the intracellular domain of APP $174 /$, it is tempting to speculate that SORLA may not only sort the mature precursor but also soluble (sAPP) or membrane-associated fragments (C99, C83) thereof (see Figure 1A).

\section{SORLA DEFICIENCY PROMOTES AMYLOIDOGENIC PROCESSING AND PLAQUE DEPOSITION}

Transgenic mouse models have been instrumental in exploring the relevance of novel risk genes for amyloidosis and plaque burden, and associated memory deficits in vivo. Models with genetically altered SORLA expression have been no exception to this rule.

As shown by Andersen and colleagues /1/ and by Rohe et al. /62/ in two different mouse models of targeted Sorll gene disruption, a loss of receptor activity results in the enhanced turnover of murine APP and, consequently, in a significant increase in amyloidogenic (sAPP $\beta, A \beta$ ) and non-amyloidogenic- 


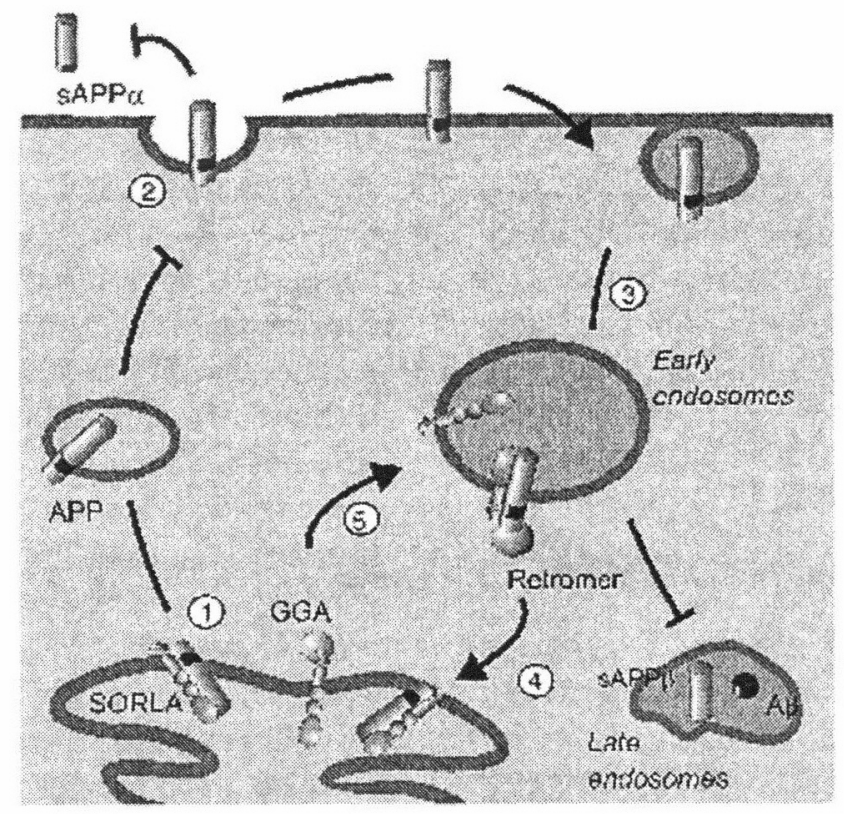

Fig. 4: SORLA guides trafficking and processing of APP. SORLA acts as sorting receptor that traps APP in the trans-Golgi network (TGN, step 1), reducing the number of precursor molecules that enter processing pathways at the cell surface (step 2, non-amyloidogenic) or in endocytic compartments (step 3, amyloidogenic). Potentially, SORLA may also shuttle APP from early endosomes back to the TGN (step 4), further reducing the extent of amyloidogenic processing in late endosomes. Retrograde endosome to TGN trafficking of SORLA/APP complexes may involve association with the retromer complex. Direct sorting of SORLA from TGN to early endosomes requires GGAs (step 5). Apart from retromer and GGAs, additional adaptors including PACS1 /66/, AP-1 /48/, X11/mint /21,32,70/, ubiquilin /22/, PAT1/85/, and SNX17/35/ may be involved in routing of APP/SORLA complexes.

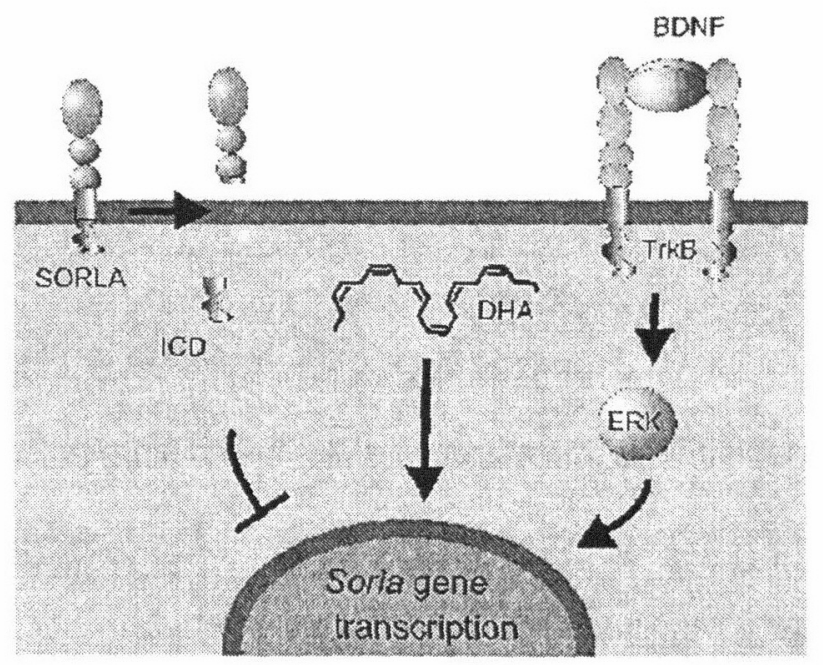

Fig. 5: Pathways that control expression of SORLA in the brain. (Left) Regulated intramembranous proteolysis releases the intracellular domain (ICD) from SORLA. It acts as negative regulator of SORLA gene transcription in the nucleus. (Middle) Docosahexaenoic acid (DHA) promotes SORLA gene transcription by yet unknown intracellular mechanisms. (Right) Brain derived neurotrophic factor (BDNF) induces SORLA gene transcription by binding to receptor tyrosine kinases (TrkB) and by subsequent stimulation of extracellular regulated kinase (ERK)-dependent signaling pathways. 
products $(\mathrm{SAPP} \alpha)$ in the brain. Introducing the murine Sorll defect into mice expressing human APP transgene variants $A p p^{\text {V717F }}$ (Ind) or $A p p^{\text {K595M/NS96L }}$ (Swe) caused a two- to threefold increase in $A \beta$ formation and plaque load /10,62/. Interestingly in both models, SORLA deficiency exacerbates early amyloid pathology, causing a forward shift in disease onset. This diseasepromoting effect is dependent on the gene dose as seen comparing animals with two $\left(\mathrm{Sorll}^{+/+}\right)$, one $\left(\right.$ Sorl $\left.^{\dagger+\alpha}\right)$, or no functional Sorll gene $\left(\right.$ Sorll $\left.{ }^{-/}\right)$, providing further experimental evidence that SORLA levels in the human brain determine risk of $\mathrm{AD} / 10 \%$.

As well as studying the effects of enhanced amyloid $\beta$ peptide formation, SORLA-deficient mouse models also enabled an analysis of the consequences of elevated levels of soluble APP products in the CNS. This question was particularly relevant given the proposed role for sAPP $\alpha$ as a stimulator of adult neurogenesis (Figure 1A) $/ 7,34 /$. In line with this hypothesis, a significant increase in SAPP $\alpha$ levels in Sorll ${ }^{/-}$ mice coincided with a profound stimulation of neuronal extracellular regulated kinase (ERK) signaling and with an enhanced adult neurogenesis in the subgranular zone of the hippocampus, providing in vivo support for the neurotrophic action of SAPP $\alpha / 62 /$.

Taken together, studies on mouse models of human SORLA deficiency documented a role for the receptor not only in control of plaque burden but also in APP-dependent neuronal signaling and suggested a molecular explanation for the increased ERK activity and enhanced adult neurogenesis observed in some $\mathrm{AD}$ patients $/ 12,27$, $47,56,86,87 /$.

\section{PATHWAYS IN CONTROL OF SORLA EXPRESSION IN THE BRAIN}

So far, little is known about genetic or environmental factors in control of SORL1 expression in the human brain. Although all available data suggest that allelic SORL1 variants may determine transcription levels, convincing evidence to support this assumption is lacking. Tentative data from quantitative RT-PCR analyses indicate that carriers of the CTT haplotype at SNPs 22-24 may have less than half the levels of the $S O R L 1$ transcript seen in carriers of the non-AD haplotype. Regression analysis, however, also shows that the SORLI haplotype status accounts for only $14 \%$ of the variance, indicating that additional factors modulate neuronal SORLA expression $/ 61 /$.

Concerning the pathways modulating SORLA activity, the intracellular domain of the receptor has been shown to be released by $\gamma$-secretase cleavage $/ 52 /$ and to act as a repressor of SORL1 transcription /6/ (Figure 5). Another regulatory pathway was uncovered by investigations of docosahexaenoic acid (DHA), an essential dietary $\omega-3$ polyunsaturated fatty acid that is implicated in AD. Higher blood levels of DHA are positively correlated with reduced risk of neurodegeneration in large epidemiological studies /28/. Dietary DHA significantly improves cognition, protects from synaptic protein loss, and lowers plaque deposition in mouse models, apparently by reducing $A B$ production $/ 15,39,54 /$. A recent report showed that DHA markedly up-regulates SORLA expression in primary neurons and in mouse models in vivo, suggesting that the protective effects of dietary fish oil supplementation may, at least in part, act through induction of SORL1 /42/ (Figure 5).

Last but not least, screening approaches in primary neurons identified brain-derived neurotrophic factor (BDNF) as a major inducer of Sorll that activates receptor gene transcription through ERK /63/ (Figure 5). In line with a physiological role as inducer of Sorl1, receptor expression was significantly impaired in mouse models with genetic $\left(B d n f^{-1}\right)$ or disease-related loss of BDNF activity in the brain (e.g., Huntington's disease) 163\%. Intriguingly, the exogenous application of $B D N F$ reduced $A \beta$ production in the brain of wildtype mice, but not in animals genetically deficient for Sorl1. The findings suggest that the beneficial effects ascribed to BDNF in APP metabolism /44/ work through the induction of SORLI encoding a negative regulator of neuronal APP processing 163/. Besides elucidating novel cellular pathways in control of SORL1 expression in the brain, the studies described above provide proof that interventions, such as dietary DHA intake or BDNF application, designed to raise receptor 
expression represent potential therapeutic approaches in the treatment of $\mathrm{AD}$.

\section{CONCLUSIONS}

Recent years have witnessed the detailed clarification of the cellular pathways in control of APP processing and their potential contribution to neurodegenerative processes in patients. In particular, the functional characterization of SORLA/SORL1, a unique sorting receptor for APP, sheds light on a previously poorly understood process concerning the targeted transport of APP to distinct intraneuronal compartments harbouring the various secretase activities. The results from histopathological and epidemiologic studies in humans further substantiate the critical role of this receptor in sporadic AD. Although much still remains to be learned about this exciting pathway, SORLA/SORL1 certainly holds great promise as a novel biomarker and perhaps even as a new drug target in the treatment of this devastating disease.

\section{ACKNOWLEDGMENT}

Work in the authors' laboratory was supported by grants from the Deutsche Forschungsgemeinschaft, the European Community (MEMORIES), the Helmholtz-Association (HELMA), and the AFI, Cologne.

\section{REFERENCES}

1. Andersen OM, Reiche J, Schmidt V, Gotthardt M, Spoelgen R, Behlke J, von Arnim CA, Breiderhoff $T$, Jansen P, Wu X, Bales KR, Cappai R, Masters CL, Gliemann J, Mufson EJ, Hyman BT, Paul SM, Nykjaer A, Willnow TE. Neuronal sorting proteinrelated receptor sorLA/LR I I regulates processing of the amyloid precursor protein. Proc Natl Acad Sci USA 2005;102(38):13461-6.

2. Andersen OM, Schmidt V, Spoelgen R, Gliemann J, Behlke J, Galatis D, McKinstry WJ, Parker MW, Masters CL, Hyman BT, Cappai R, Willnow TE. Molecular dissection of the interaction between amyloid precursor protein and its neuronal trafficking receptor SorLA/LR11. Biochemistry 2006;45(8):2618-2628.
3. Andersen OM, Willnow TE. Lipoprotein receptors in Alzheimer's disease. Trends Neurosci 2006;29 (12):687-94.

4. Baum AE, Akula N, Cabanero M, Cardona I, Corona W, Klemens B, Schulze TG, Cichon S, Rietschel M, Nothen MM, Georgi A, Schumacher J, Schwarz M, Abou Jamra R, Hofels S, Propping P, Satagopan J, Detera-Wadleigh SD, Hardy J, McMahon FJ. A genome-wide association study implicates diacylglycerol kinase eta (DGKH) and several other genes in the etiology of bipolar disorder. Mol Psychiatry 2008;13(2):197-207.

5. Bettens K, Brouwers N, Engelborghs S, De Deyn $\mathrm{PP}$, Van Broeckhoven C, Sleegers K. SORL1 is genetically associated with increased risk for lateonset Alzheimer disease in the Belgian population. Hum Mutat 2008;29(5):769-70.

6. Bohm C, Seibel N, Henkel B, Steiner H, Haass C, Hampe W. SorLA signaling by regulated intramembrane proteolysis. J Biol Chem 2006.

7. Caille I, Allinquant B, Dupont E, Bouillot C, Langer A, Muller U, Prochiantz A. Soluble form of amyloid precursor protein regulates proliferation of progenitors in the adult subventricular zone. Development 2004;131(9):2173-81.

8. Cellini E, Tedde A, Bagnoli S, Pradella S, Piacentini S, Sorbi S, Nacmias B. Implication of sex and SORL1 variants in Italian patients with Alzheimer disease. Arch Neurol 2009;66(10):1260-6.

9. Cleary JP, Walsh DM, Hofmeister JJ, Shankar GM, Kuskowski MA, Selkoe DJ, Ashe KH. Natural oligomers of the amyloid-beta protein specifically disrupt cognitive function. Nat Neurosci 2005;8(1):79-84.

10. Dodson SE, Andersen OM, Karmali V, Fritz JJ, Cheng D, Peng J, Levey AI, Willnow TE, Lah JJ. Loss of LR11/SORLA enhances early pathology in a mouse model of amyloidosis:evidence for a proximal role in Alzheimer's disease. $\mathrm{J}$ Neurosci 2008;28(48): 12877-86.

11. Dodson SE, Gearing M, Lippa CF, Montine TJ, Levey AI, Lah JJ. LR11/SorLA expression is reduced in sporadic Alzheimer disease but not in familial Alzheimer disease. J Neuropathol Exp Neurol 2006;65(9):866-72.

12. Ferrer I, Blanco R, Carmona M, Ribera R, Goutan E, Puig B, Rey MJ, Cardozo A, Vinals F, Ribalta T. Phosphorylated map kinase (ERK1, ERK2) expression is associated with early tau deposition in neurones and glial cells, but not with increased nuclear DNA vulnerability and cell death, in Alzheimer disease, Pick's disease, progressive supranuclear palsy and corticobasal degeneration. Brain Pathol 2001;11(2):144-58. 
13. Feulner TM, Laws SM, Friedrich $P$, Wagenpfeil S, Wurst SH, Riehle C, Kuhn KA, Krawczak M, Schreiber S, Nikolaus S, Forstl H, Kurz A, Riemenschneider M. Examination of the current top candidate genes for $\mathrm{AD}$ in a genome-wide association study. Mol Psychiatry 2009.

14. Gliemann J, Hermey G, Nykjaer A, Petersen CM, Jacobsen C, Andreasen PA. The mosaic receptor sorLA/LR1 1 binds components of the plasminogen activating system and PDGF-BB similarly to low density lipoprotein receptor-related protein (LRP1) but mediates slow internalization of bound ligand. Biochem J 2004;38 1(Pt 1):203-12.

15. Green KN, Martinez-Coria $\mathrm{H}$, Khashwji $\mathrm{H}$, Hall EB, Yurko-Mauro KA, Ellis L, LaFerla FM. Dietary docosahexaenoic acid and docosapentaenoic acid ameliorate amyloid-beta and tau pathology via a mechanism involving presenilin 1 levels. J Neurosci 2007;27(16):4385-95.

16. Grupe A, Li Y, Rowland C, Nowotny P, Hinrichs AL, Smemo S, Kauwe JS, Maxwell TJ, Cherny S, Doil L, Tacey $\mathrm{K}$, van Luchene $\mathrm{R}$, Myers A, Wavrant-De Vrieze F, Kaleem $M$, Hollingworth P, Jehu L, Foy C, Archer N, Hamilton G, Holmans P, Morris CM, Catanese J, Sninsky J, White TJ, Powell J, Hardy J, O'Donovan M, Lovestone S, Jones L, Morris JC, Thal L, Owen M, Williams J, Goate A. A scan of chromosome 10 identifies a novel locus showing strong association with late-onset Alzheimer disease. Am J Hum Genet 2006;78(1):78-88.

17. Haass C, Hung AY, Schlossmacher MG, Teplow DB, Selkoe DJ. beta-Amyloid peptide and a 3$\mathrm{kDa}$ fragment are derived by distinct cellular mechanisms. J Biol Chem 1993;268(5):3021-4.

18. Hampe W, Rezgaoui M, Hermans-Borgmeyer I, Schaller HC. The genes for the human VPS10 domain-containing receptors are large and contain many small exons. Hum Genet 2001;108(6):529-36.

19. Hardy J, Selkoe DJ. The amyloid hypothesis of Alzheimer's disease:progress and problems on the road to therapeutics. Science 2002;297(5580):353-6.

20. Hermey G, Riedel IB, Hampe W, Schaller HC, Hermans-Borgmeyer I. Identification and characterization of SorCS, a third member of a novel receptor family. Biochem Biophys Res Commun 1999;266(2):347-51.

21. Hill K, Li Y, Bennett M, McKay M, Zhu X, Shern J, Torre E, Lah JJ, Levey AI, Kahn RA. Munc18 interacting proteins:ADP-ribosylation factordenendent coat proteins that regulate the traffic of beta-Alzheimer's precursor protein. J Biol Chem 2003;278(38):36032-40.

22. Hiltunen $M$, Lu A, Thomas AV, Romano DM, Kim M, Jones PB, Xie Z, Kounnas MZ, Wagner SL, Berezovska O, Hyman BT, Tesco G, Bertram
L, Tanzi RE. Ubiquilin 1 modulates amyloid precursor protein trafficking and Abeta secretion. J Biol Chem 2006;281(43):32240-53.

23. Jacobsen L, Madsen $P$, Jacobsen C, Nielsen MS, Gliemann J, Petersen CM. Activation and functional characterization of the mosaic receptor SorLA/LR11. J Biol Chem 2001;276(25):22788-96.

24. Jacobsen L, Madsen P, Moestrup SK, Lund AH, Tommerup N, Nykjaer A, Sottrup-Jensen L, Gliemann J, Petersen CM. Molecular characterization of a novel human hybrid-type receptor that binds the alpha2-macroglobulin receptor-associated protein. J Biol Chem 1996;271(49):31379-83.

25. Jacobsen L, Madsen P, Nielsen MS, Geraerts WP, Gliemann J, Smit AB, Petersen CM. The sorLA cytoplasmic domain interacts with GGAl and -2 and defines minimum requirements for GGA binding. FEBS Lett 2002;511(1-3):155-8.

26. Jansen $P$, Giehl K, Nyengaard JR, Teng K, Lioubinski $O$, Sjoegaard SS, Breiderhoff $T$, Gotthardt M, Lin F, Eilers A, Petersen CM, Lewin GR, Hempstead BL, Willnow TE, Nykjaer A. Roles for the pro-neurotrophin receptor sortilin in neuronal development, aging and brain injury. Nat Neurosci 2007;10(11):1449-57.

27. Jin K, Peel AL, Mao XO, Xie L, Cottrell BA, Henshall DC, Greenberg DA. Increased hippocampal neurogenesis in Alzheimer's disease. Proc Natl Acad Sci USA 2004;101(1):343-7.

28. Johnson EJ, Schaefer EJ. Potential role of dietary n-3 fatty acids in the prevention of dementia and macular degeneration. Am J Clin Nutr 2006;83(6 Suppl):1494S-1498S.

29. Kanaki T, Bujo H, Hirayama S, Tanaka K, Yamazaki H, Seimiya K, Morisaki N, Schneider WJ, Saito Y. Developmental regulation of LR11 expression in murine brain. DNA Cell Biol 1998; 17(8):647-57.

30. Khvotchev M, Sudhof TC. Proteolytic processing of amyloid-beta precursor protein by secretases does not require cell surface transport. J Biol Chem 2004;279(45):47101-8.

31. Kimura R, Yamamoto M, Morihara T, Akatsu H, Kudo T, Kamino K, Takeda M. SORLl is genetically associated with Alzheimer disease in a Japanese population. Neurosci Lett 2009;461(2): 177-80.

32. King GD, Perez RG, Steinhilb ML, Gaut JR, Turner RS. X11alpha modulates secretory and endocytic trafficking and metabolism of amyloid precursor protein:mutational analysis of the YENPTY sequence. Neuroscience 2003;120(1): 143-54.

33. Kolsch $H$, Jessen F, Wiltfang J, Lewczuk $P$, Dichgans M, Teipel SJ, Kornhuber J, Frolich L, Heuser I, Peters O, Wiese B, Kaduszkiewicz H, 
van den Bussche $\mathrm{H}$, Hull $\mathrm{M}$, Kurz A, Ruther E, Henn FA, Maier W. Association of SORL1 gene variants with Alzheimer's disease. Brain Res 2009;1264:1-6.

34. Kwak YD, Choumkina E, Sugaya K. Amyloid precursor protein is involved in staurosporine induced glial differentiation of neural progenitor cells. Biochem Biophys Res Commun 2006;344 (1):431-7.

35. Lee J, Retamal C, Cuitino L, Caruano-Yzermans A, Shin JE, van Kerkhof P, Marzolo MP, Bu G. Adaptor protein sorting nexin 17 regulates amyloid precursor protein trafficking and processing in the early endosomes. $\mathrm{J}$ Biol Chem 2008;283(17):11501-8.

36. Lee JH, Cheng R, Schupf N, Manly J, Lantigua R, Stern Y, Rogaeva E, Wakutani Y, Farrer L, St George-Hyslop P, Mayeux R. The association between genetic variants in SORL1 and Alzheimer disease in an urban, multiethnic, community-based cohort. Arch Neurol 2007;64 (4):501-6.

37. Lesne S, Koh MT, Kotilinek L, Kayed R, Glabe CG, Yang A, Gallagher M, Ashe KH. A specific amyloid-beta protein assembly in the brain impairs memory. Nature 2006;440(7082):352-7.

38. Li Y, Rowland C, Catanese J, Morris J, Lovestone $\mathrm{S}$, O'Donovan $\mathrm{MC}$, Goate A, Owen M, Williams J, Grupe A. SORL1 variants and risk of late-onset Al-heimer's disease. Neurobiol Dis 2008;29(2):293-6.

39. Lim GP, Calon F, Morihara T, Yang F, Teter B, Ubeda O, Salem N, Jr., Frautschy SA, Cole GM. A diet enriched with the omega-3 fatty acid docosahexaenoic acid reduces amyloid burden in an aged Alzheimer mouse model. J Neurosci 2005;25(12):3032-40.

40. Lu T, Pan Y, Kao SY, Li C, Kohane I, Chan J, Yankner BA. Gene regulation and DNA damage in the ageing human brain. Nature 2004;429 (6994):883-91.

41. Ma QL, Galasko DR, Ringman JM, Vinters HV, Edland SD, Pomakian J, Ubeda OJ, Rosario ER, Teter B, Frautschy SA, Cole GM. Reduction of SorLA/LR11, a sorting protein limiting betaamyloid production, in Alzheimer disease cerebrospinal fluid. Arch Neurol 2009;66(4):448-57.

42. Ma QL, Teter B, Ubeda OJ, Morihara T, Dhoot D, Nyby MD, Tuck ML, Frautschy SA, Cole GM. Omega-3 fatty acid docosahexaenoic acid increases SorLA/LR11, a sorting protein with reduced expression in sporadic Alzheimer's disease (AD):relevance to AD prevention. J Neurosci 2007;27(52):14299-307.

43. Marcusson EG, Horazdovsky BF, Cereghino JL, Gharakhanian E, Emr SD. The sorting receptor for yeast vacuolar carboxypeptidase $\mathrm{Y}$ is encoded by the VPS10 gene. Cell 1994;77(4):579-86.

44. Matrone C, Ciotti MT, Mercanti D, Marolda R, Calissano P. NGF and BDNF signaling control amyloidogenic route and Abeta production in hippocampal neurons. Proc Natl Acad Sci USA 2008;105(35):13139-44.

45. Motoi Y, Aizawa T, Haga S, Nakamura S, Namba $Y$, Ikeda K. Neuronal localization of a novel mosaic apolipoprotein $\mathrm{E}$ receptor, LR11, in rat and human brain. Brain Res 1999;833(2):209-15.

46. Muhammad A, Flores I, Zhang H, Yu R, Staniszewski A, Planel E, Herman M, Ho L, Kreber R, Honig LS, Ganetzky B, Duff K, Arancio O, Small SA. Retromer deficiency observed in Alzheimer's disease causes hippo-campal dysfunction, neurodegeneration, and Abeta accumulation. Proc Natl Acad Sci USA 2008;105 (20):7327-32.

47. Nagy $Z$. The last neuronal division:a unifying hypothesis for the pathogenesis of Alzheimer's disease. J Cell Mol Med 2005;9(3):531-41.

48. Nielsen MS, Gustafsen C, Madsen P, Nyengaard JR, Hermey G, Bakke O, Mari M, Schu P, Pohlmann R, Dennes A, Petersen CM. Sorting by the cytoplasmic domain of the amyloid precursor protein binding receptor SorLA. Mol Cell Biol 2007.

49. Nilsson SK, Christensen S, Raarup MK, Ryan RO, Nielsen MS, Olivecrona G. Endocytosis of apolipoprotein $\mathrm{A}-\mathrm{V}$ by members of the low density lipoprotein receptor and the VPS10p domain receptor families. J Biol Chem 2008;283 (38):25920-7.

50. Nixon RA, Cataldo AM. Lysosomal system pathways: genes to neurodegeneration in Alzheimer's disease. J Alzheimers Dis 2006;9(3 Suppl):277-89.

51. Nothwehr SF, Ha SA, Bruinsma P. Sorting of yeast membrane proteins into an endosome-toGolgi pathway involves direct interaction of their cytosolic domains with Vps35p. J Cell Biol 2000; 151(2):297-310.

52. Nyborg AC, Ladd TB, Zwizinski CW, Lah JJ, Golde TE. Sortilin, SorCS1b, and SorLA Vps10p sorting receptors, are novel gamma-secretase substrates. Mol Neurodegener 2006;1:3.

53. Offe K, Dodson SE, Shoemaker JT, Fritz JJ, Gearing M, Levey AI, Lah JJ. The lipoprotein receptor LR11 regulates amyloid beta production and amyloid precursor protein traffic in endosomal compartments. J Neurosci 2006;26(5): 1596-603.

54. Oksman M, Iivonen $H$, Hogyes E, Amtul Z, Penke B, Leenders I, Broersen L, Lutjohann D, Hartmann $T$, Tanila $H$. Impact of different saturated fatty acid, polyunsaturated fatty acid and cholesterol containing diets on beta-amyloid accumulation in APP/PS l transgenic mice. Neurobiol Dis 2006;23(3):563-72. 
55. Peraus GC, Masters CL, Beyreuther K. Late compartments of amyloid precursor protein transport in SY5Y cells are involved in betaamyloid secretion. J Neurosci 1997;17(20):7714-24.

56. Perry G, Roder H, Nunomura A, Takeda A, Friedlich AL, Zhu X, Raina AK, Holbrook N, Siedlak SL, Harris PL, Smith MA. Activation of neuronal extracellular receptor kinase (ERK) in Alpheimer disease links oxidative stress to abnormal phosphorylation. Neuroreport 1999;10 (11):2411-5.

57. Petersen CM, Nielsen MS, Nykjaer A, Jacobsen L, Tommerup $\mathrm{N}$, Rasmussen $\mathrm{HH}$, Roigaard $\mathrm{H}$, Gliemann J, Madsen P, Moestrup SK. Molecular identification of a novel candidate sorting receptor purified from human brain by receptor-associated protein affinity chromatography. $\mathrm{J}$ Biol Chem 1997;272(6):3599-605.

58. Quistgaard EM, Madsen P, Groftehauge MK, Nissen P, Petersen CM, Thirup SS. Ligands bind to Sortilin in the tunnel of a ten-bladed betapropeller domain. Nat Struct Mol Biol 2009;16 (1):96-8.

59. Reynolds CA, Hong MG, Eriksson UK, Blennow K, Johansson B, Malmberg B, Berg S, Gatz M, Pedersen NL, Bennet AM, Prince JA. Sequence variation in SORL1 and dementia risk in Swedes. Neurogenetics;11(1):139-42.

60. Rezgaoui M, Hermey G, Riedel IB, Hampe W, Schaller HC, Hermans-Borgmeyer I. Identification of SorCS2, a novel member of the VPS10 domain containing receptor family, prominently expressed in the developing mouse brain. Mech Dev 2001; 100(2):335-8.

61. Rogaeva E, Meng Y, Lee JH, Gu Y, Kawarai T, Zou F, Katayama T, Baldwin CT, Cheng $R$, Hasegawa $H$, Chen F, Shibata N, Lunetta KL, Pardossi-Piquard R, Bohm C, Wakutani Y, Cupples LA, Cuenco KT, Green RC, Pinessi L, Rainero I, Sorbi S, Bruni A, Duara R, Friedland RP, Inzelberg R, Hampe W, Bujo H, Song YQ, Andersen OM, Willnow TE, Graff-Radford N, Petersen RC, Dickson D, Der SD, Fraser PE, Schmitt-Ulms G, Younkin S, Mayeux R, Farrer LA, St GeorgeHyslop P. The neuronal sortilin-related receptor SORL1 is genetically associated with Alzheimer disease. Nat Genet 2007;39(2): 168-77.

62. Rohe M, Carlo AS, Breyhan H, Sporbert A, Militz D, Schmidt V, Wozny C, Harmeier A, Erdmann B, Bales KR, Wolf S, Kempermann G, Paul SM, Schmitz D, Bayer TA, Willnow TE, Andersen OM. Sortilin-related receptor with A-type repeats (SORLA) affects the amyloid precursor proteindependent stimulation of ERK signaling and adult neurogenesis. J Biol Chem 2008;283(21):14826-34.
63. Rohe M, Synowitz M, Glass R, Paul SM, Nykjaer A, Willnow TE. Brain-derived neurotrophic factor reduces amyloidogenic processing through control of SORLA gene expression. J Neurosci 2009;29 (49): $15472-8$.

64. Sager KL, Wuu J, Leurgans SE, Rees HD, Gearing M, Mufson EJ, Levey AI, Lah JJ. Neuronal LR11/sorLA expression is reduced in mild cognitive impairment. Ann Neurol 2007;62 (6):640-7.

65. Scherzer CR, Offe K, Gearing M, Rees HD, Fang G, Heilman CJ, Schaller C, Bujo H, Levey AI, Lah JJ. Loss of apolipoprotein $E$ receptor LR11 in Alzheimer disease. Arch Neurol 2004;61(8):1200-5.

66. Schmidt V, Sporbert A, Rohe M, Reimer T, Rehm A, Andersen OM, Willnow TE. SorLA/LR11 regulates processing of amyloid precursor protein via interaction with adaptors GGA and PACS-1. J Biol Chem 2007;282(45):32956-64.

67. Seaman MN. Recycle your receptors with retromer. Trends Cell Biol 2005;15(2):68-75.

68. Selivanova A, Winblad B, Farmery MR, Dantuma NP, Ankarcrona $M$. COPI-mediated retrograde transport is required for efficient gamma-secretase cleavage of the amyloid precursor protein. Biochem Biophys Res Commun 2006;350(1):220-6.

69. Selkoe DJ. Alzheimer's disease: genotypes, phenotypes, and treatments. Science 1997;275 (5300):630-1.

70. Shrivastava-Ranjan P, Faundez V, Fang G, Rees H, Lah JJ, Levey AI, Kahn RA. Mint3/X1 lgamma is an ADP-ribosylation factor-dependent adaptor that regulates the traffic of the Alzheimer's Precursor protein from the trans-Golgi network. Mol Biol Cell 2008;19(1):51-64.

71. Small SA. Retromer sorting:a pathogenic pathway in late-onset Alzheimer disease. Arch Neurol 2008;65(3):323-8.

72. Small SA, Gandy S. Sorting through the cell biology of Alzheimer's disease: intracellular pathways to pathogenesis. Neuron 2006;52(1):15-31.

73. Small SA, Kent K, Pierce A, Leung C, Kang MS, Okada H, Honig L, Vonsattel JP, Kim TW. Model-guided microarray implicates the retromer complex in Alzheimer's disease. Ann Neurol 2005;58(6):909-19.

74. Spoelgen $\mathrm{R}$, von Arnim CA, Thomas AV, Peltan ID, Koker M, Deng A, Irizarry MC, Andersen OM, Willnow TE, Hyman BT. Interaction of the cytosolic domains of sorLA/LR11 with the amyloid precursor protein (APP) and beta-secretase beta-site APP-cleaving enzyme. J Neurosci 2006;26(2):418-28.

75. Tan EK, Lee J, Chen CP, Teo YY, Zhao Y, Lee WL. SORL1 haplotypes modulate risk of Alzheimer's disease in Chinese. Neurobiol Aging 2007. 
76. Tesco G, Koh YH, Kang EL, Cameron AN, Das S, Seha-Esteves M, Hiltunen M, Yang SH, Zhong Z, Shen Y, Simpkins JW, Tanzi RE. Depletion of GGA3 stabilizes BACE and enhances betasecretase activity. Neuron 2007;54(5):721-37.

77. von Arnim CA, Spoelgen R, Peltan ID, Deng M, Courchesne S, Koker M, Matsui T, Kowa $\mathrm{H}$, Lichtenthaler SF, Irizarry MC, Hyman BT. GGA1 acts as a spatial switch altering amyloid precursor protein trafficking and processing. $\mathbf{J}$ Neurosci 2006;26(39):9913-22.

78. Wahle $T$, Thal DR, Sastre $M$, Rentmeister A, Bogdanovic N, Famulok M, Heneka MT, Walter J. GGA1 is expressed in the human brain and affects the generation of amyloid beta-peptide. $J$ Neurosci 2006;26(49):12838-46.

79. Walsh DM, Klyubin I, Fadeeva JV, Cullen WK, Anwyl R, Wolfe MS, Rowan MJ, Selkoe DJ. Naturally secreted oligomers of amyloid beta protein potently inhibit hippocampal long-term potentiation in vivo. Nature 2002;416(6880):535-9.

80. Westergaard UB, Sorensen ES, Hermey G, Nielsen MS, Nykjaer A, Kirkegaard K, Jacobsen C, Gliemann J, Madsen P, Petersen CM. Functional organization of the sortilin Vps10p domain. J Biol Chem 2004;279(48):50221-9.

81. Willnow TE, Petersen CM, Nykjaer A. VPS10Pdomain receptors - regulators of neuronal viability and function. Nat Rev Neurosci 2008;9(12):899-909.
82. $\mathrm{Xu} \mathrm{H}$, Greengard $\mathrm{P}$, Gandy $\mathrm{S}$. Regulated formation of Golgi secretory vesicles containing Alzheimer beta-amyloid precursor protein. J Biol Chem 1995; 270(40):23243-5.

83. Yamazaki H, Bujo H, Kusunoki J, Seimiya K, Kanaki T, Morisaki N, Schneider WJ, Saito Y. Elements of neural adhesion molecules and a yeast vacuolar protein sorting receptor are present in a novel mammalian low density lipoprotein receptor family member. J Biol Chem 1996;271 (40):24761-8.

84. Yamazaki T, Selkoe DJ, Koo EH. Trafficking of cell surface beta-amyloid precursor protein: retrograde and transcytotic transport in cultured neurons. J Cell Biol 1995;129(2):431-42.

85. Zheng P, Eastman J, Vande Pol S, Pimplikar SW. PAT1, a microtubule-interacting protein, recognizes the basolateral sorting signal of amyloid precursor protein. Proc Natl Acad Sci USA 1998; 95(25):14745-50.

86. Zhu $X$, Castellani RJ, Takeda A, Nunomura A, Atwood CS, Perry G, Smith MA. Differential activation of neuronal ERK, JNK/SAPK and $\mathrm{p} 38$ in Alzheimer disease:the 'two hit' hypothesis. Mech Ageing Dev 2001;123(1):39-46.

87. Zhu X, Sun Z, Lee HG, Siedlak SL, Perry G, Smith MA. Distribution, levels, and activation of MEK1 in Alzheimer's disease. J Neurochem 2003; 86(1):136-42. 